\title{
Feed Quality, Prevalence of Aflatoxin Contamination in Dairy Feed and Raw Milk in Oromia Special Zone Surrounding Finfinne, Ethiopia
}

\author{
Jalel Fikadu1, Berhan Tamir², Ulfina Galmessa ${ }^{3}$, Kefena Effa ${ }^{3}$
}

10.18805/ajdfr.DR-233

\begin{abstract}
Background: The study was attended in Oromia special zone around Finfinne with the objective to asses feed quality composition, detect and quantify the amount of aflatoxine (AFM1) in raw cow's milk and AFB1 in home-mixed feed of dairy.

Methods: For this purpose, 90 milk and 90 samples of feed from dairy farmers were collected. Analysis for AFM1 and AFB1 was conducted by high-performance liquid chromatography.

Result: The study discovered that the occurrence of AFM1 in all samples of milk and detection level ranged from $0.02 \mathrm{ppb}$ to $0.08 \mathrm{ppbL}$. Overall, $64(71.1 \%)$ out of a total of 90 milk samples contained less than or equal to $0.05 \mathrm{ppb}$ of AFM1. Moreover, $26(28.9 \%)$ milk samples exceeded $0.05 \mathrm{ppb}$. All the feed samples were contaminated with AFB1 minimum 12.67ppb and a maximum of 45.67ppb. Overall, out of a total of 90 feed samples collected, about $66(73.3 \%)$ contained AFB1 at a level less than or equal to $20 \mathrm{ppb}$. At the same time, $34(26.7 \%)$ of the feed samples contained AFB1 at a level exceeding $20 \mathrm{ppb}$. The Linear regression displayed that the significant associations between the presence of AFB1 in the feed and the levels of adulteration in AFM1 in milk. The level of aflatoxin pollution found during this study in milk and feed ought to prompt action to spot appropriate interventions. These results recommend that risk mitigation should focus on reducing aflatoxin impurity in raw materials feed which can ultimately minimize AFM1 in milk.
\end{abstract}

Key words: Aflatoxin, Aspegillus fungi, Contamination, Dairy, Feed, Home-mixed, Milk.

\section{INTRODUCTION}

A flatoxins are the best hurtful secondary metabolites of some genus fungi like Aspegillus flavus, A. parasiticas and infrequently $A$. nomius, that square measure present contaminants of animal Feeds and human food (AbdelFattah et al., 1982). Aflatoxins may be separated into aflatoxins AFG1, AFG2, AFB1 and AFB2 (Akiama et al., 2001). Aflatoxin $B 1$ could be a genotoxic and cancer plant toxin that's made by A.flavus and A. parasiticas. AFB1 can be processed to aflatoxin 11 within ruminant livestock. AflatoxinB1 within feeds can decrease production, slow fertility plus to these increase susceptibility to infections (Senerwa et al, 2016). These both types of toxins have reflected to be cancer-causing and geno -toxic to end-user. When consumed, aflatoxinB1 is hydroxylate to aflatoxinM1 and secreted within milk (Applebaum et al., 1982). Aflatoxin B1 is specific significance, because it has been happened in most feeds/foods and is extremely malignant neoplastic disease, initiating liver disease in humans (Liu et al., 2012). Elevated amount of AflatoxinB1 within the food end in elevated stages of aflatoinM1 in milk and milk product.

In addition, every aflatoxinB1 and aflatoxinM1 unit of measurement are class field by international Agency for Analysis on malignancy as category cancer-causing agent (Universal Agency for analysis on Cancer, 2002). This implies that milk and completely different milk product would possibly contain toxins that make a threat to humans, considerably kids United Nations agency consume it. Moreover, exposure to aflatoxins can cause growth
${ }^{1}$ Department of Animal Science, College of Agriculture and Natural Resources Assosa University, P. O. Box 18, Assosa, Ethiopia. 2Department of Animal Production, College of Veterinary Medicine and Agriculture, Addis Ababa University P. O. Box 34, Bishoftu, Ethiopia.

${ }^{3}$ Ethiopia Institute of Agricultural Research (EIAR), Holeta Agricultural Research Center, Ethiopia.

Corresponding Author: Jalel Fikadu, Department of Animal Science, College of Agriculture and Natural Resources Assosa University, P. O. Box 18, Assosa, Ethiopia.

Email: jalelyadeta@gmail.com

How to cite this article: Fikadu, J., Tamir, B., Galmessa, U. and Effa, K. (2021). Feed Quality, Prevalence of Aflatoxin Contamination in Dairy Feed and Raw Milk in Oromia Special Zone Surrounding Finfinne, Ethiopia. Asian Journal of Dairy and Food Research. DOI: 10.18805/ajdfr.DR-233.

Submitted: 30-03-2021 Accepted: 22-10-2021 Online: 06-11-2021

impairment (Khlangwiset et al., 2011) and disorder (Bondy and Pestka, 2000) in animals and humans. Substantial association between impaired child growth and bioweapon coverage was reportable from several countries in SubSaharan continent further as Benin, (Gong et al., 2004) and land (Okoth and Ohingo, 2004).

For these reasons, Ethiopia standard agency collaborated to Veterinary drug and feed administration regulator authority considered strict limitations for aflatoxin regulation. The extreme amounts are 20ppb of AFB1 has 
been recognized in dairy feed. Also the last Commission Regulation of the European Union (EU) No 165/2010 determine the determined level is $8 \mathrm{mg} / \mathrm{kg}$ of AFB1 has been established in food subjected to sorting or physical treatment before human consumption and also the corresponding 2 $\mathrm{mg} / \mathrm{kg}$ of AFB1 for direct human consumption. The determined level of $0.05 \mathrm{ppb}$ has been set for AFM1 in milk by Ethiopia Food and Medicine control Authority (FMCA) derived from FAO and WHO. The Feed and Drug Management in the USA (USFDA) sets action level for AflatoxinM1 in milk and total aflatoxinB1 in animal feed to be $0.5 \mathrm{ppb}$ and $20 \mathrm{ppb}$ correspondingly (National Grain and Food Association, 2011). Few research have stated Aflatoxin impurity of milk and dairy feeds in the Greater Addis Ababa milk shed, Ethiopia (Gizachew et al 2016). Therefore, there is limited study about aflatoxine impurity of dairy feed and milk in Oromia special zone around Finfinne. The present study was therefore designed to assess feed quality, detect the amount of aflatoxineB1 detoxification of dairy feed and aflatoxin $\mathrm{M} 1$ in milk.

\section{MATERIALS AND METHODS}

\section{Description of the study areas}

The research has done on private urban dairy farms in Oromia special zone surround Finfinne, Ethiopia. It's situated at an altitude ranging between 1700-3600 m.a.s.I. The common lowest and highest annual temperatures are $120 \mathrm{C}$ and $160 \mathrm{C}$, respectively. With the bimodal rain fall pattern, the mean yearly rain fall is between $800-226 \mathrm{~mm}$. The long and heavy rainfall is received from June to September while the short and small shower is received from February to April.

\section{Sampling}

Experimental samples were collected from Oomia special Zone surround Finfinne, Ethiopia. The data set includes milk samples collected at every dairy long with a home-mixed dairy farm feeds sample for aflatoxin analysis. Three urban centers of Oromia special zone surrounding Finfine (Burayu,Sululta and Sebeta) have purposively designated for this work based on the Zone Agriculture Office report on the amount of milk production. 90 milk samples of concerning $500 \mathrm{~mL}$ and 90 home dairy mixed feed samples of concerning $500 \mathrm{~g}$ collected from every city. Milk samples analyzed for aflatoxin level at Bless Agri Food Laboratory Services PLC, (ISO 17025-2005 Accredited) in Lega Dadhi lega xafo, Ethiopia and feed samples analyzed for aflatoxin level and chemical composition at the Laboratory of Animal product, Veterinary drug and feed quality assessment center in Addis Ababa. Determination of aflatoxin for both milk and feed have analyzed using a very competent method of Higher Performance Liquid Chromatography (HPLC) techniques and for chemical composition of feed was used Near-infrared - NIR Technology.

\section{Analysis of AFM1 in milk}

The sample should keep in the refrigerator before the analysis proceeds, take about $100 \mathrm{ml}$ of the sample and warm-up it at $40^{\circ} \mathrm{C}$. Centrifuge the warmed sample and remove the upper layer and repeat the centrifuge if there is a layer that is not thin. Take $50 \mathrm{ml}$ of sample and set in the clean-up system (which uses the immunoaffinity column (Aflaclean M1) of Aflatoxin M1) and Eluate by $3 \mathrm{ml}$ of Acetonitrile and evaporate. Reconstitute the residue by $1 \mathrm{ml}$ of acetonitrile. Inject the reconstituted solution using HPLC System and analyze the chromatogram from HPLC and take the result. This was according to the procedure determination of Aflatoxin M1 (AOAC 2000.08).

\section{Analysis of sflatoxinB1 in home-mixed dairy feed}

Determination of aflatoxin B1 Extraction and clean-up procedure: A test portion of $20 \mathrm{~g}$ feed sample and extraction solution of $2 \mathrm{~g} \mathrm{NaCl}$ with $80 \mathrm{~mL}$ methanol and $20 \mathrm{~mL}$ deionized water was used. Finally, $50 \mathrm{~mL}$ of hexane was added to the prepared sample. A pressure pumper was used to extract and the therefore final extract was collected within the column reservoir and therefore the solution was passed undergone filtration. Aflatoxin derivatization: After adding n-hexane (200 $\mu \mathrm{L}$ ) within the derivatization vial to re-dissolve aflatoxin, 50 $\mu \mathrm{L}$ of trifluoroacetic acid is added and it's mixed on a vortex mixer for $30 \mathrm{sec}$. Layers are allowed to separate and an aqueous layer (lower layer) containing aflatoxins is filtered and so injected onto the LC column. Liquid chromatography determination with fluorescence detection: The mobile phase (acetonitrile: methanol: deionized water within the ratio of $20: 20: 60$ ) is degassed with sonicator before use. Aflatoxin B1 peak is identified in derivatized extract chromatograms by comparing its retention time with the corresponding peak within the standard chromatogram. The number of the aflatoxin was resolve within the derivatized extract (injected) from the respective standard curves (AOAC, 1997).

\section{Feed quality compositions analysis}

At farm mixed concentrate feed samples were collected from every farm and sealed in plastic luggage for chemical analyses. Chemical analyses of the feed samples were performed at the animal product, Veterinary drug and Feed quality assessment Center's Laboratory. The DM and ash contents of feed samples were determined by oven drying at $105^{\circ} \mathrm{C}$ overnight and by igniting during a muffle furnace at $600^{\circ} \mathrm{C}$ for $6 \mathrm{hrs}$, correspondingly (AOAC, 1990). Nitrogen (N) content was resolve by the Kjeldahl techniques and crude protein (CP) was calculated as $\mathrm{N}^{*} 6.25$ (McDonald et al., 2002). The two-stage in vitro technique developed by Tilley and Terry (1963) was accustomed confirm in vitro organic matter digestibility (IVOMD) of the feeds. Metabolizable energy (ME) was calculable from the IVOMD as

$$
\mathrm{ME}(\mathrm{MJ} / \mathrm{kg} \mathrm{DM})=0.016 \times(\mathrm{g} / \mathrm{kg} \text { IVOMD })
$$

(McDonald et al., 2002)

\section{Statistical analysis}

The stage adulteration of aflatoxinM1 in all samples was designed based on the quantity of aflatoxinM1 $0.05 \mathrm{ppb}$ (ESA, 2009). The finding of current study was compared with Ethiopia standard agency limit and Ethiopia veterinary 
Feed Quality, Prevalence of Aflatoxin Contamination in Dairy Feed and Raw Milk in Oromia Special Zone Surrounding...

drug and feed administration control Authority, if the concentration of aflatoxin in feed is more than $20 \mathrm{ppb}$ it'll not be safe to fed dairy cattle. The total mean of aflatoxin amount and its concentration was determined using SPSS 20 statistical software package.

\section{RESULTS AND DISCUSSION}

\section{Chemical composition of home mixed dairy feed}

The mean farm-mixed feed chemical compositions of laboratory test result are given in Table 1 . The mean feed mixed at home contents of DM and Crude Protein (CP) within current study area was $898.63 \pm 1.92 \mathrm{~g} / \mathrm{kg}$ and $160.22 \pm$ $4.54 \mathrm{~g} / \mathrm{kg}$, correspondingly. The mean CP content of the study area was slightly equivalent to the minimum requirements $170 \mathrm{~g} / \mathrm{kg}$ or $17 \%$ of Ethiopian standard agency (ES6403: 2019) total crude protein (CP) in dairy cattle feed. The overall mean value of OM and Ash in home-mixed feed in the current study was $799.11 \pm 2.35 \mathrm{~g} / \mathrm{kg}$ and $99.51 \pm 1.43$ $\mathrm{g} / \mathrm{kg}$ correspondingly. The overall mean ME value of the home-mixed concentrate feed where mixed to fed crossbred dairy cattle was $2428.22 \pm 45.93 \mathrm{kcalg} / \mathrm{kg}$ of DM. This is lower than the minimum requirements $2500 \mathrm{Kcalg} / \mathrm{kg}$ of Ethiopian feed quality standard (ES6403:2019) metabolic energy (ME) of dairy feed. The mean value of crude fat, crude fiber and Moisture in the study was $39.88 \pm 1.11 \mathrm{~g} / \mathrm{kg}$, $154.15 \pm 5.04 \mathrm{~g} / \mathrm{kg}$ and $113.33 \pm 10.94 \mathrm{~g} / \mathrm{kg}$ respectively which were highly lower than the maximum requirement $1000 \mathrm{~g} /$ $\mathrm{kg}, 15 \mathrm{~g} / \mathrm{kg}$ and $1100 \mathrm{~g} / \mathrm{kg}$ (ES6403:2019) of Ethiopian standard correspondingly. The chemical conformation of feed in the study area were no statistically significant different $(p>0.05)$ among the study town.

\section{Aflatoxin B1 contamination in home mixed dairy feeds}

A total of 90 samples animal feed (30 from every site) was gathered for laboratory analysis. The samples included all the commonly used home mixed dairy feeds such as wheat bran, nougseed cake, wheat middling, linseed cake, bean hulls, cottonseed meal, salt and brewery by-product. The finding discovered that, the minimum stage of AflatoxinB1 contamination was $12 \mathrm{ppb}$ and the maximum AflatoxinB1 amount was $46 \mathrm{ppb}$ (Table 2). The overall mean of AflatoxinB1 in the study area, $22.42 \pm 1.87 \mathrm{pbb}$ was higher than tolerance level of Ethiopia standard 20ppb (ES6403:2019). The mean AFlatoxinB1 pollution value was significantly $(p<0.05)$ higher in Sululta than Burayu and Sebata. There is no statistically significant between Burayu and Sebeta.

It was observed that all the 90 feed samples collected were moderately contaminated with aflatoxin B1 in different level (Fig 1), 73.3\% contained AFB1 at a level less than or equal to 20ppb of the Ethiopia standard (ES6403:2019), mean that it will safe to fed lactating cow. While $26.7 \%$ of the feed samples contained AFB1 at a level exceeding Ethiopian standard (20 ppb), this is not safe for feeding lactating cow.

\section{Aflatoxin M1 contamination in milk}

The finding of analyzed sample shown that all milk were spoiled with AflatoxinM1 within a median value of $0.042 \mathrm{ppb}$ (Table 3). The uppermost AFM1 content was $0.08 \mathrm{ppb}$ from Sululta and Burayu and the lowermost was $0.02 \mathrm{ppb}$ from Sebata. The overall mean value of the result of study was $0.044 \mathrm{ppb}$ that was moderately lower than the Ethiopian standard regulatory limits or $\mathrm{FAO} / \mathrm{WHO}$ of $0.05 \mathrm{ppb}$ aflatoxins M1 in milk.

Out of collected samples, $64(71.1 \%)$ sampled occurred aflatoxinM1 at stage of less than or equal to $0.05 \mathrm{ppb}$ or Ethiopia tolerance level (ES 2009) and 26 (28.9\%) was exceed at the level of Ethiopia limits of detection (Fig 2). Even small percentage of milk sample is contaminated by AFM1 but the number is significant, since it was above safety tolerance level.

Table 1: Chemical composition of home-mixed concentrate mixtures in dairy farms Oromia special zone around Finfine.

\begin{tabular}{|c|c|c|c|c|c|}
\hline Nutritive value & $\begin{array}{l}\text { Burayu } \\
\mathrm{N}=30\end{array}$ & $\begin{array}{l}\text { Sululta } \\
\mathrm{N}=30\end{array}$ & $\begin{array}{l}\text { Sebata } \\
N=30\end{array}$ & $\begin{array}{l}\text { Over all mean } \\
\qquad \mathrm{N}=90\end{array}$ & P-value \\
\hline DM & $898.24^{\mathrm{a}} \pm 3.34$ & $891.14^{\mathrm{a}} \pm 0.77$ & $906.52^{\mathrm{a}} \pm 1.65$ & $898.63 \pm 1.92$ & 0.001 \\
\hline OM & $785.46^{a} \pm 3.73$ & $805.3^{a} \pm 1.09$ & $806.58^{\mathrm{a}} \pm 2.24$ & $799.11 \pm 2.35$ & 0.0002 \\
\hline $\mathrm{CP}$ & $152.52^{a} \pm 2.98$ & $166.3^{a} \pm 5.48$ & $161.84^{a} \pm 5.17^{a}$ & $160.22 \pm 4.54$ & 0.003 \\
\hline Fat & $34.82^{\mathrm{a}} \pm 1.52$ & $33.15^{a} \pm 0.78$ & $51.69^{a} \pm 1.04$ & $39.88 \pm 1.11$ & 0.0001 \\
\hline ME kcal g/kg & $2415.3^{a} \pm 50.64$ & $2403.6^{\mathrm{a}} \pm 47.38$ & $2465.8^{a} \pm 39.8$ & $2428.22 \pm 45.93$ & 0.04 \\
\hline Starch & $185.78^{a} \pm 8.35$ & $325.02^{a} \pm 15.79$ & $271.3^{a} \pm 59.85$ & $260.68 \pm 27.99$ & 0.026 \\
\hline Ash & $112.78^{a} \pm 1.91$ & $85.83^{a} \pm 0.96$ & $99.9^{a} \pm 1.41$ & $99.51 \pm 1.43$ & 0.0019 \\
\hline Fiber & $155.6^{a} \pm 6.26$ & $143.56^{a} \pm 5.04$ & $163.29 \mathrm{a} \pm 3.82$ & $154.15 \pm 5.04$ & 0.027 \\
\hline
\end{tabular}

Table 2: Aflatoxin B1 contamination of Home mixed dairy feeds in the Oromia special zone around Finfinne.

\begin{tabular}{lcccc}
\hline AFB1 in ppb & Burayu & Sululta & Sebeta & Overall \\
& $\mathrm{N}=30$ & $\mathrm{~N}=30$ & $\mathrm{~N}=30$ & $\mathrm{~N}=90$ \\
\hline Mean & $21.99^{\mathrm{b}} \pm 1.75$ & $23.37^{\mathrm{a}} \pm 1.95$ & $21.9^{\mathrm{b}} \pm 1.9$ & $22.42 \pm 1.87$ \\
Median & 18.00 & 18.5 & 18 & 18.17 \\
Minimum & 12 & 14 & 12 & 12.67 \\
Maximum & 46 & 46 & 45 & 45.67 \\
\hline
\end{tabular}




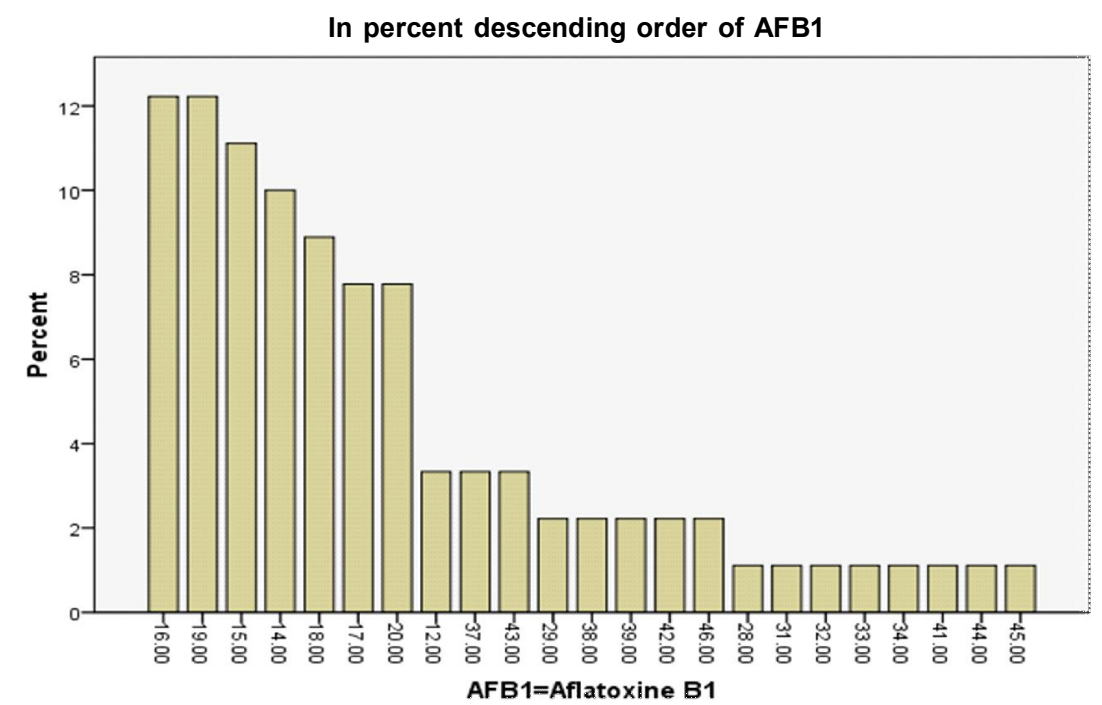

Fig 1: Contamination of feed samples with AFB1 (ppb) in the Oromia special zone around Finfine.

Table 3: Aflatoxin M1 contamination of milk in the Oromia special zone around Finfine.

\begin{tabular}{lcccc}
\hline AFM1ppb & $\begin{array}{c}\text { Burayu } \\
\mathrm{N}=30\end{array}$ & $\begin{array}{c}\text { Sululta } \\
\mathrm{N}=30\end{array}$ & $\begin{array}{c}\text { Sebata } \\
\mathrm{N}=30\end{array}$ & $\begin{array}{c}\text { Overall mean } \\
\mathrm{N}=90\end{array}$ \\
\hline Mean & 0.0431 & 0.0454 & 0.0431 & 0.044 \\
SD & 0.0154 & 0.017 & 0.0150 & 0.016 \\
Medium & 0.0420 & 0.043 & 0.042 & 0.042 \\
Minimum & 0.02 & 0.03 & 0.02 & 0.023 \\
Maximum & 0.08 & 0.08 & 0.07 & 0.0766 \\
\hline
\end{tabular}

\section{Correlation between AFM1 in milk and AFB1 in feed}

The parametric statistics of regression coefficient of the study was totally different from zero (Table 4) which advocates that the regression model showed there was clear association among aflatoxin $\mathrm{M} 1$ impurity of milk and the occurrence of aflatoxinsB1 within the feed. This means that there was a strong positive relationship among aflatoxin $\mathrm{M} 1$ adulteration in raw milk and AFB1 within the feed. In this finding within a correlation coefficient 0.932 , the feed contained aflatoxineB 1 would have resulted milk with aflatoxinsM1. However, some farm farms had discrepancies between the amount of toxin contamination in their milk and feed, sometimes there is the occurrences of high aflatoxin $\mathrm{M} 1$ in milk but less aflatoxinB1 in feed and vice versa.

In the present study, the overall mean value of CP was considerably greater than the value $(150 \mathrm{~g} / \mathrm{kg} \mathrm{DM})$ of compound fed mixture recommended by Delgado and Randel (1989) for cows grazing tropical grass swards. The mean Crude Protein of the present finding was less than $216.58 \pm 20.86 \mathrm{~g} / \mathrm{kg}$ DM stated by Assaminew (2014) and $260 \mathrm{~g} / \mathrm{kg}$ DM reported by Mesfin et al. (2013) in the urban, as well as periurban production system of dairy cattle in Holeta and home-mixed compound feed mixture for cross bred lactating dairy cattle in the highlands of Ethiopia correspondingly. But it has comparable with finding reported by Nega et al. (2006) in the urban and periurban area of the Central Rift Valley, Ethiopia who report $163 \mathrm{~g} / \mathrm{kg} \mathrm{DM}$ of CP in the farmer home-mixed concentrate for cross-bred lactating dairy cattle. The home-mixed concentrate mixture for lactating cross-bred cattles is considerably variable and unbalanced for the CP contents; the ingredients were blended in the concentrate mixture without any standards. The mean metabolic energy (ME) content result in this result was less than the report of Rehrahie et al. (2003); Mesfin et al. (2013); Tekeba et al., (2013) who showed closer to 2866.8 $\mathrm{kcal} / \mathrm{kg} \mathrm{DM}$ of ME. The present result was similar to and $2532.34 / \mathrm{kg}$ DM of ME content of the finding of Nega et al. (2006) and $2580.12 \mathrm{kcal} / \mathrm{kg} \mathrm{DM}$ of ME with the finding of Mesfin et al. (2013) in farmers' home-mixed feed to dairy cows of Central Rift Valley and central Ethiopia, respectively.

The present study discovered that all feed samples had detectable with different levels of aflatoxinsB1, this finding was agreed with the result of Gizachew et al. (2016) for AflatoxinM1 impurity of milk and AflatoxinB1 with in dairy feeds in the Greater Addis Ababa milk shed. The current study showed that significant numbers of home mixed dairy feed aflatoxinB1contamination exceeded the maximum limit of detection (20 ppb) set by the Ethiopian standard agency that regulated by the Ethiopia veterinary drug and feed administration control authority (VDFACA). In the current study result aflatoxin $\mathrm{B} 1$ contamination level was lower than Compound feed collected from great Addis Ababa milk shed, with an average concentration of a minimum of $7 \mu \mathrm{g} / \mathrm{kg}(7$ $\mathrm{ppb})$ and a maximum of $419 \mu \mathrm{g} / \mathrm{kg}(419 \mathrm{ppb})$ that reported by (Gizachew et al. 2016). In The current result, overall mean contamination of AFB1 levels were above the Ethiopia standard limit $(20 \mathrm{ppb})$, this result agreement with Aflatoxin M1 in raw milk and aflatoxin B1 in the feed from household cattle in Singida, Tanzania (Salum et al. 2016). The high impurity levels of Home mixed dairy feed perceived during data collection at study sites can be attributed to the fact 


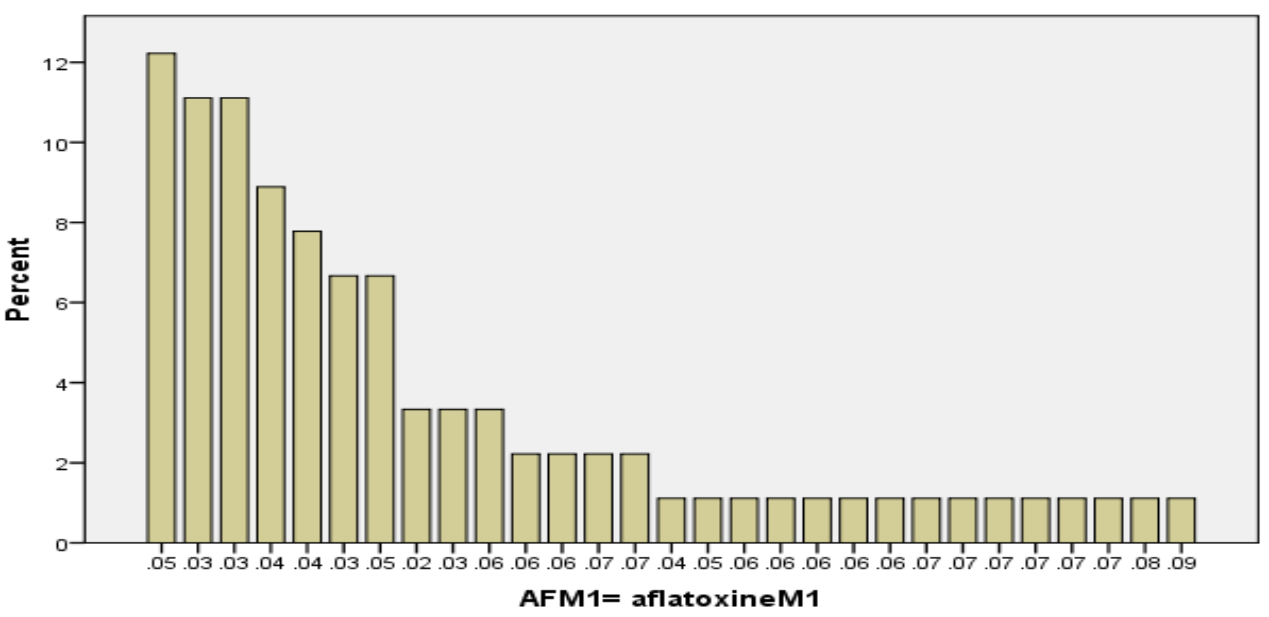

Fig 2: Contamination of milk samples with $A F m 1(p p b)$ in the Oromia special zone around Finfine.

Table 4: Linear regression model showing relationship of Aflatoxin B1in feed and level of aflatoxin M1 in milk.

\begin{tabular}{lccccrr}
\hline Source & Sum of Squares & Mean Square & Coefficient & 95\% Confidence interval & F & P-value \\
\hline Regression & 0.019 & 0.019 & 0.932 & $0.001-0.002$ & 581.281 & 0.0001 \\
Residual & 0.003 & 0.00 & & & & \\
Total & 0.012 & 0.019 & & & & \\
\hline
\end{tabular}

Predictors: (constant), AFB1= AflatoxineB1, Dependent Variable: AFM1= Aflatoxine.

that the storage facilities feed raw materials were very poor. The majority of the farmers were not aware of the presence of aflatoxins in animal feed and their impact on animal health as well as human health. Furthermore, farmers tend to buy the raw materials of feed-in bulk during the low price season and store them for extended periods in poor storage facilities. Inadequate studies have been reported on aflatoxins in dairy feeds in Sub-Saharan Africa with the exception Kenya, where substantial analysis of aflatoxin contamination of maize has been carried out (Kang'ethe et al., 2007; Ogana and Muture, 2005). In Ethiopia, young calves are especially susceptible to the harmful effects of aflatoxins before their rumen matures and they consume their mother's milk until weaning. Therefore, the economic losses due to chronic exposure of cattle to aflatoxins could be significant to the urban dairy industry in Ethiopia (Gizachew et al. 2016).

The amount number of aflatoxin contamination of home mixed feed in Sululta town was significantly greater than Buyayu and Sebeta. Though all dairy farmers of the different towns used similar types of feed raw materials, differences in environmental temperature condition, moisture and storage situations might be the cause for the variation of aflatoxin impurity between areas. In dairy cow, feeding of very high levels of aflatoxins bases for critical toxicosis and death, while chronic ingestion of lower levels can cause liver injury, gastrointestinal dysfunction and failure in appetite, reproductive role, growth, average daily intake, body weight and production (Khlangwiset et al., 2011).

This study revealed that all milk samples had detectable with different levels of AFM1. The present study result is similar with a previous finding that conducted on Aflatoxin contamination of milk and dairy feeds in the Greater Addis Ababa milk shed, Ethiopia (Gizachew et al. 2016) but the detoxification levels perceived in the present study were lower than those stated by the same authors. The more number of milk samples have not exceeded the limit of $0.05 \mathrm{ppb}$ set by the Ethiopia standard or WHO/FAO, however non disregarded percentage of them were exceeded the levels of tolerance. The maximum contamination of AFM1 that spotted in milk was less than the finding from urban centers in Kenya that has reported AFM1 levels up to 0.68 ppb (Kang ' ethe and Lang' a, 2009) and the concentration of AFM1 contamination in raw milk collected from Khartoum state in Sudan, with an average level of $2.07 \mathrm{ppb}$ and maximum of $6.9 \mathrm{ppb}$ (Elzupir and Elhussein, 2010). While the Incidence of AFM1 in the present study is slightly similar when compared to a previous study conducted on the Presence of Aflatoxin M1 in Milk, data sample Collected from Jeddah, Saudi Arabia (Magda et al, 2017) were contaminated and the quantity of AFM1 ranged from $0.09-0.65 \mathrm{ppb}$ with the mean value of $0.04 \mathrm{ppb}$ which is lower than the Euro-limit $(0.05 \mathrm{ppb})$ while 6 samples exceed the USA limit $(0.5 \mathrm{ppb})$.

The recent study discovered that, there were a moderate optimistic relation among aflatoxinM1 contamination in milk and aflatoxinB1 in the feed. The high level of aflatoxin B1 in feed correlation with high level impurity of milk with aflatoxin M1. The maximum level of aflatoxinM1 pollution in Sululta farm milk and the corresponding AFB1 levels in the feed. There were some disagreements between the contamination 
Feed Quality, Prevalence of Aflatoxin Contamination in Dairy Feed and Raw Milk in Oromia Special Zone Surrounding...

levels of milk and feed collected from the dairy farms. For example, the four farms in burayu had high levels of AFM1 in the milk while corresponding feed samples were only moderately polluted with AFB1. Inversely, a high amount of feed contamination was not always reflected in the milk. The cause could be that either at the time when milk samples were being taken, the cattle were fed dissimilar stock of feed, or the feed was not mixed well such that the study analysis didn't have an exact representation of the different feeds in the mix, this report agrees with previous study Aflatoxin uncleanness of milk and dairy feeds in the Greater Addis Ababa milk shed, Ethiopia (Gizachew et al., 2016). In livestock, feeding of very high levels of aflatoxins bases for acute toxicities and death, while chronic consumption of lower levels can cause liver damage, gastrointestinal dysfunction and decrease in appetite, reproductive function, growth, average daily gain, bodyweight and production (Khlangwiset et al., 2011).

\section{CONCLUSION}

It could be decided that from the present findings that aflatoxinM1 presence in milk is public health concern and hence all the efforts should be made to keep the levels below the recommended levels. Such efforts need all-inclusive tactic and all the serious control points of entry of aflatoxinB1 into the feed chain has to be monitored and controlled. The bioconversion of aflatoxin B1 to aflatoxinM1 in the liver depends on many factors and in Ethiopia, it is recommended to keep M1 levels below $0.05 \mathrm{ppb}$.

\section{ACKNOWLEDGEMENT}

The authors appreciatively acknowledge Bless Agri Food Laboratory Services PLC and Animal product, Veterinary Drug and Feed Quality Assessment Center Laboratory in Addis Ababa for supporting with laboratory facilities of this study. Addis Ababa University College of Veterinary Medicine and Agriculture and Ethiopia Veterinary Drug and Feed Admiration Control Authority (VDFACA) are also acknowledged for their financial support of this study. Prodigious appreciation goes to the community and dairy farmers, milk collectors and milk sellers of Burayu Sululta and Sebeta areas for their unreserved cooperation during the collection of samples for this study.

\section{REFERENCES}

Assaminew, S. (2014). Assessment of feed formulation and feeding practices for urban and Peri Urban dairy cows around Holetta Ethiopia.

Abdel-Fattah, H.M., Kamel, Y., Megalla, S.E. and Hafez, A.H. (1982). Aflatoxin and aflatoxicosis. I. fungal flora of some food and animal feeds with special references to aflatoxinproducing abilities. Mycopathologia. 77(3): 129e135.

Akiama, H. Goda, Y., Tanaka, T. and Toyoda, M. (2001). Determination of aflatoxins B1, B2, G1 and G2 in spices using multifunctional column clean-up. Journal of Chromatography A. $932: 153 \mathrm{e} 157$.
AOAC (1990). Definition of the methods for analyzing total nitrogen in fertilizers.

AOAC (1997). Definition of the methods for analyzing of aflatoxin contamination in feed.

AOAC (2000.08). Official Methods of Aflatoxin M1 in liquid milk immune affinity column by liquid Chromatography.

Applebaum, R.S., Brackett, R.E., Wiseman, D.W. and Marth, E.H. (1982). Responses of dairy cows to dietary aflatoxin: feed intake and yield, toxin content and quality of milk of cows treated with pure and impure aflatoxin. Journal of Dairy Science. 65(8): 1503-1508.

Brackett, R.E., Wiseman, D.W. and Marth, E.H. (1982). Responses of dairy cows to dietary aflatoxin: Feed intake and yield, toxin content and quality of milk of cows treated with pure and impure aflatoxin. Journal of Dairy Science. 65(8): 1503-1508.

Bondy, G.S., and Pestka, J.J. (2000). Immunomodulation by fungal toxins. Journal of Toxicology and Environmental Health Part B: Critical Review. 3: 109-143.

ESA (Ethiopian Standard Agency) (2009). Unprocessed Whole/Raw Cow Milk Specification. $2^{\text {nd }}$ ed., ES: 3460

Elzupir, A.O., and Elhussein, A.M. (2010). Determination of aflatoxin M1 in dairy cattle milk in Khartoum state, Sudan. Food Control. 21: 945-946.

Gizachew, D., Barbara, S., Azage, T., Jean, H. and Delia, G. (2016). Aflatoxin contamination of milk and dairy feeds in the Greater Addis Ababa milk shed, Ethiopia. Food Control. 59: 773.

Gong, Y., Hounsa, A., Egal, S., Turner, P.C., Sutcliffe, A.E., Hall, A.J., et al. (2004). Post-weaning exposure to aflatoxin results in impaired child growth: A longitudinal study in Benin, West Africa. Environmental Health Perspectives. 112(13): 1334-1338.

International Agency for the Research on Cancer (IARC). (2002). Aflatoxins. Monograph on the evaluation of carcinogenic risks to humans. Lyon: IARC Press.

Kang'ethe, E.K., M'Ibui, G.M., Randolph, T.F. and Lang'at, A.K. (2007). Prevalence of aflatoxin M1 and B1 in milk and animal feeds from urban smallholder dairy production in Dagoretti Division, Nairobi, Kenya. East African Medical Journal. 84(11 Suppl): S83eS86.

Kang'ethe, E.K. and Lang'a, K.A. (2009). Aflatoxin B1 and M1 contamination of animal feeds and milk from urban centers in Kenya. African Health Sciences. 9(4): 218e226.

Khlangwiset, P., Shephard, G.S. and Wu, F. (2011). Aflatoxins and growth impairment: A review. Critical Reviews in Toxicology. 41(9): $740 \mathrm{e} 755$.

Liu, Y., Chang, C.C., Marsh, G.M. and Wu, F. (2012). Population attributable risks of aflatoxin- related liver cancer: Systematic review and meta-analysis. Eurasian Journal of Cancer. 48(14).

Magda, A., Fardos B. Amany Al. and Samar, R. (2017). Presence of Aflatoxin M1 in Milk Samples Collected from Jeddah, Saudi Arabia.

McDonald P., Edwards R.A., Greenhalgh J.F.D. and Morgan C.A. (2002). Animal Nutrition. $6^{\text {th }}$ ed. Pearson Education Limited. Edinburgh, Great Britain. 
Feed Quality, Prevalence of Aflatoxin Contamination in Dairy Feed and Raw Milk in Oromia Special Zone Surrounding...

Mesfin, D. Tamirat, S. Getu, K. Getnet, A. and Aemiro, K. (2013). On-farm evaluation ofurea molasses multi-nutrient block (UMMB) and concentrate mixture as a supplement to crossbred lactating dairy cows in peri-urban dairy production system of Central Ethiopia. Pp. 121-131.

Livestock Research Proceedings of the (2012). Annual National Workshop on Review of Livestock Research Results, at EIAR, Addis Ababa, Ethiopia, EIAR.

Muture, B.N. and Ogana, G. (2005). Aflatoxin levels in maize and maize products during the 2004 food poisoning outbreak in Eastern Province of Kenya. East African Medical Journal. 82(6): $275 \mathrm{e} 279$.

National Grain and Feed Association. (2011). FDA mycotoxin regulatory guidance. A guide for grain elevators, feed manufacturers, grain processors and exporters. Available at Accessed 12.02.15 www.ngfa.org

Nega, T. Pravee, V., Pornsri, C. and Suwapong, S. (2006). Comparative performances of Holstein-Friesian cows under smallholder and large scale farmers' management in central rift valley, Ethiopia. Kasetsart J. 40: 58-68.

Okoth, S.A. and Ohingo, M. (2004). Dietary aflatoxin exposure and impaired growth in young children from Kisumu District, Kenya: cross sectional study. African Journal of Health Sciences. 11(1e2): 43e54.
Rehrahie, M., Yohannes, G. and Agajie, T. (2003). Evaluation of the general farm characteristics and dairy herd structure in urban and peri-urban dairy production system in the Addis Ababa milk shed. Proceedings of the $10^{\text {th }}$ Annual Conference of the Ethiopian Society of Animal Production (ESAP). Addis Ababa, Ethiopia, 22-24 August 2002, Ethiopian Society of Animal Production, Addis Ababa, Ethiopia. Pp. 347-354.

Salum Mohammed, Joan J.E Munissi and Stephen S. Nyandoro (2016). Aflatoxin M1 in raw milk and aflatoxin B1 in feed from household cows in Singida, Tanzania. http://dx.doi. org/10.1080/19393210.2015.1137361

Senerwa, D., Sirma, A., Mtimet, N., Kang'ethe, E., Grace, D. and Lindahl, J.F. (2016). Prevalence of aflatoxin in feeds and cow milk from five counties in Kenya.

Tekeba, E., Wurzinger, M., Baldinger, L. and Zollitsch, W.J. (2013). Effects of dietary supplementation with urea molasses multi-nutrient block on performance of mid lactating local Ethiopian and crossbred dairy cows. Livestock Research for Rural Development. Volume 25, Article\#96. Retrieved April 9, 2014, from http://www.Irrd.org/lrrd25/6/teke25096.htm. Tilley, J.M.A. and Terry R.A.A (1963). Two-stage technique for the in vitro digestion of forage crops. J. Brit. Grassland Soc. 18: $104-11$ 